\title{
A Sensitive Assay for Rapid Detection and Quantification of Aphanomyces euteiches in Soil
}

\author{
Christophe Gangneux, Marc-Antoine Cannesan, Mélanie Bressan, Lisa Castel, Anne Moussart, \\ Maïté Vicré-Gibouin, Azeddine Driouich, Isabelle Trinsoutrot-Gattin, and Karine Laval
}

First, second, third, fourth, eighth, and ninth authors: Unité Agri'Terr, Esitpa, 3 rue du Tronquet, CS40118, F-76134 Mont-Saint-Aignan, France; second, sixth, and seventh authors: Laboratoire Glycobiologie et Matrice Extracellulaire Végétale, EA 4358, Université de Rouen, F-76821 Mont Saint Aignan, France; and fifth author: INRA, UMR1349 IGEPP, F-35653 Le Rheu, France, Union Nationale Interprofessionnelle des Plantes Riches en Protéines (UNIP), 11 rue de Monceau-CS60003-F-75378 Paris. Accepted for publication 31 March 2014.

\begin{abstract}
Gangneux, C., Cannesan, M.-A., Bressan, M., Castel, L., Moussart, A., Vicré-Gibouin, M., Driouich, A., Trinsoutrot-Gattin, I., and Laval, K. 2014. A sensitive assay for rapid detection and quantification of Aphanomyces euteiches in soil. Phytopathology 104:1138-1147.

Aphanomyces euteiches is a widespread oomycete pathogen causing root rot in a wide range of leguminous crops. Losses can reach up to $100 \%$ for pea culture and there is currently no registered pesticide for its control. Crop management remains the most efficient tool to control root rot, and avoidance of infested soil seems to be the optimal solution. A test was developed to identify fields suitable for pea crops, consisting of the

determination of the inoculum potential of soil using baiting plants. A new rapid, specific, and sensitive molecular method is described allowing the quantification of less than 10 oospores per gram of soil. This challenge is achieved by a real-time polymerase chain reaction procedure targeting internal transcribed spacer 1 from the ribosomal DNA operons. A preliminary study based on typical soils from northwestern France demonstrated that the A. euteiches oospore density in soil is related to the inoculum potential. Furthermore, this method has proved sensitive enough to accurately study the influence of biotic factors that may govern the actual emergence of root rot.
\end{abstract}

Aphanomyces euteiches is the causal agent for root rot of a wide range of leguminous crops (pea, alfalfa, beans, and clovers). Symptoms caused by $A$. euteiches are very similar in all hosts but vary in timing or intensity (24). Briefly, after germination of oospores in the presence of root exudates and formation of sporangium, mobile zoospores swim toward the maturation and elongation zones of roots where they encyst $(10,27)$. Cysts germinate and mycelium progresses through the root tissues where honey-colored lesions develop. Lesions may then be invaded by opportunistic organisms such as Pythium, Phoma, Rhizoctonia, and Fusarium and usually turn dark (24). The total collapse of root tissue causes yellowing and wilting of aerial plant parts. Subsequently, fewer pods are produced containing a reduced number of seeds. This oomycete is widespread in North America, Europe, Japan, Australia, and New Zealand and is considered one of the main soilborne cryptogamic agents impairing yields, especially for pea culture for which losses can reach up to $100 \%$ in the wetter regions of the world $(10,17,18,58)$. Because $A$. euteiches belongs to the oomycota phylum (filamentous protist), there is no specific fungicide available to control it (2). The use of metalaxyl, a chemical widely used against other oomycete pathogen, has been forbidden in Europe since 2005 and its substitution, the metalaxyl-M, has also been shown to be ineffective against $A$. euteiches (7). Some dinitroaniline herbicides have been used with moderate success, especially in Japan and in the United States in the 1970 s to 1980 s $(19,50,51)$, but those molecules were not reregistered because of their toxicity for animals and aquatic

Corresponding author: C. Gangneux; E-mail address: cgangneux@esitpa.fr

http://dx.doi.org/10.1094/PHYTO-09-13-0265-R

(c) 2014 The American Phytopathological Society organisms $(8,53)$. Without a chemical solution, biological control of root rot caused by $A$. euteiches has provided a vast field of investigation since the 1990s. Several microorganisms (Clonostachys rosea [60], Pseudomonas cepacia [28], Burkholderia cepaci [29], Bacillus subtilis and Paenibacillus polymyxa [5], and Bacillus mycoides [56]) showed encouraging effects in vitro but application to field conditions showed only slight or no effect on root rot emergence and intensity. A few natural compounds have demonstrated protective effects on pea infection by A. euteiches but there is still no study which demonstrates that those products would be effective on the field scale for commercial production. For example, the 2,4-diacetylphloroglucinol from Pseudomonas fluorescens suppresses the zoosporogenesis and impairs motility of Peronosporomycete zoospores in vitro (26). Nicotinamide extracted from pea cotyledons or ArabinoGalactan proteins (AGP) extracted from roots promote the encystement of zoospores at some distance from plant roots and leads to oospore conversion or suicidal germination, respectively $(10,11,46)$.

Ultimately, crop management remains the most effective lever to control pea root rot. First, by genetic selection of challenging traits: breeders have been searching for resistance to A. euteiches for some time (13) and partially resistant pea genotypes have been developed since the recent identification of new quantitative trait loci in the pea genome (20). Second, by incorporating green manure from Brassicaceae or some Poaceae that contain glucosinolates or saponins, respectively. Degradation products from Brassicacaeae are toxic sulfur-containing compounds that inhibit zoospore formation, motility, and germination $(31,48,49)$, while saponins, such as $\beta$-escin, possess a wider toxicity pattern against Aphanomyces (15). Third, crop rotation may appear effective to control the disease but the atypical viability of oospores in soil (up to 20 years) in combination with the large panel of alternative hosts that may sustain the pathogen reduces the interest of this option (40). However, the introduction in the crop rotation of non- 
host species or resistant cultivars of vetch or faba beans contributed to the reduction of the inoculum potential (IP) of soils (34). Finally, to date, disease avoidance appears to be the most dependable practice to control root rot of pea. In France, a test has been developed to identify fields suitable for pea crops (35). It consists of sowing pea in soil pots for 14 to 21 days with optimal humidity and temperature for disease emergence. The IP of soil is then evaluated on a 0 to 5 scale $(33,42)$. This predictive diagnosis method is now recommended by most stakeholders of the sector but has failed to gain momentum. Based on the in planta method developed by Vandemark et al. (54) and Vandemark and Grünwald (55), Sauvage et al. (44) proposed an alternative rapid assay envisaging a direct quantification of oospores in soils by molecular methods. However the method does not allow for the detection of less than 200 A. euteiches oospores per gram of soil. Herein we propose a new fast, specific, and sensitive molecular method for prediction of the IP of a soil. This challenge is achieved by a realtime polymerase chain reaction (PCR) procedure targeting internal transcribed spacer 1 (ITS1) from the ribosomal DNA (rDNA) operons, allowing the detection of less than 10 A. euteiches oospores per gram of soil. The effectiveness of the methods have been proved for different types of soil, sterilized or not, with artificial inoculations of two strains of A. euteiches with low or high virulence.

\section{MATERIALS AND METHODS}

Aphanomyces isolates. All isolates of Aphanomyces spp. used in this study (Table 1) were provided by the French National Institute for Agronomic Research (INRA). Isolates were maintained on corn meal agar (CMA) slants at $10^{\circ} \mathrm{C}$ for long-term storage or grown in Sabouraud-dextrose broth (BioMérieux, Marcy l'Etoile, France) for genomic DNA extractions.

Genomic DNA extraction and assay from Aphanomyces spp. isolates. DNA was extracted using the PowerPlant DNA Isolation Kit (MoBio Laboratories, Carlsbad, CA) from $200 \mathrm{mg}$ of fresh Aphanomyces spp. mycelium grown in Sabouraud-dextrose broth. DNA was quantified by fluorimetry using the Quant-iT dsDNA Broad-Range Assay Kit (Life Technologies, Carlsbad, CA).

Oospore production and purification. Aphanomyces spp. oospores were produced in oat meal broth $(\mathrm{OMB})$ prepared by heating a solution of blended oat flakes $(20 \mathrm{~g}$ per liter $)$ at $80^{\circ} \mathrm{C}$ for $1 \mathrm{~h}$. After filtration through a polypropylene wintering veil $\left(30 \mathrm{~g} \mathrm{~m}^{-2}\right)$, $\mathrm{pH}$ was adjusted to 6.9 before autoclaving. Sterilized OMB $(125 \mathrm{ml})$ was dispensed in cell culture flasks $\left(185 \mathrm{~cm}^{2}\right.$; Thermo Fisher Scientific, Waltham, MA) and inoculated with a mycelial plug from a CMA slant. After 3 weeks at $20^{\circ} \mathrm{C}$, mycelium was transferred in a chilled microblender containing $4 \mathrm{ml}$ of sterile molecular biology grade water. After a 2-min blending,

TABLE 1. Characteristics of Aphanomyces isolates for A. cladogamus, A. cochlioides, and A. euteiches ${ }^{\mathrm{a}}$

\begin{tabular}{|c|c|c|c|c|c|}
\hline Aphanomyces species & Isolate/strain code & Source/origin & Virulence type $^{b}$ & Amplification status & ITS1 copy number ${ }^{c}$ \\
\hline A. cochlioides & I & France (Brittany) & I & - & / \\
\hline A. cladogamus & l & France (Brittany) & I & - & I \\
\hline A. euteiches & Ae4 & France (Isle of France) & ND & + & 49 \\
\hline A. euteiches & Ae7 & France (Brittany) & $\mathrm{I}$ & + & 86 \\
\hline A. euteiches & Ae8 & France (Picardy) & ND & + & 84 \\
\hline A. euteiches & Ae10 & France (Normandy) & VIII & + & 103 \\
\hline A. euteiches & Ae15 & France (Isle of France) & ND & + & 119 \\
\hline A. euteiches & Ae16 & France (Isle of France) & VIII & + & 81 \\
\hline A. euteiches & Ae22 & France (Central France) & $\mathrm{X}$ & + & 95 \\
\hline A. euteiches & Ae24 & France (Isle of France) & ND & + & 131 \\
\hline A. euteiches & Ae40 & France (Aquitaine) & $\mathrm{I}$ & + & 115 \\
\hline A. euteiches & Ae52 & France (Brittany) & $\mathrm{I}$ & + & 60 \\
\hline A. euteiches & Ae59 & France (Central France) & I & + & 66 \\
\hline A. euteiches & Ae76 & France (Normandy) & I & + & 104 \\
\hline A. euteiches & Ae79 & France (Central France) & ND & + & 99 \\
\hline A. euteiches & Ae81 & France (Champagne-Ardenne) & $\mathrm{I}$ & + & 114 \\
\hline A. euteiches & Ae84 (RB84) & France (Brittany) & I & + & 99 \\
\hline A. euteiches & Ae87 & USA & I & + & 50 \\
\hline A. euteiches & Ae92 & France (Brittany) & I & + & 61 \\
\hline A. euteiches & Ae97 & France (Brittany) & ND & + & 94 \\
\hline A. euteiches & Ae101 & France (Brittany) & ND & + & 145 \\
\hline A. euteiches & Ae105 & France (Isle of France) & ND & + & 120 \\
\hline A. euteiches & Ae112 & USA & ND & + & 96 \\
\hline A. euteiches & Ae115 & France (Isle of France) & I & + & 79 \\
\hline A. euteiches & Ae119 & France (Aquitaine) & $\mathrm{I}$ & + & 91 \\
\hline A. euteiches & Ae139 & New Zealand & IV & + & 96 \\
\hline A. euteiches & Ae140 & USA & ND & + & 93 \\
\hline A. euteiches & Ae146 & Sweden & $\mathrm{I}$ & + & 100 \\
\hline A. euteiches & Ae153 & Australia & ND & + & 97 \\
\hline A. euteiches & Ae156 & Australia & ND & + & 97 \\
\hline A. euteiches & Ae163 & Canada (Quebec) & $\mathrm{V}$ & + & 111 \\
\hline A. euteiches & Ae164 & Canada (Quebec) & VI & + & 83 \\
\hline A. euteiches & Ae165 & Canada (Quebec) & $\mathrm{X}$ & + & 104 \\
\hline A. euteiches & Ae174 & France (Isle of France) & ND & + & 66 \\
\hline A. euteiches & Ae185 & France (Burgundy) & ND & + & 114 \\
\hline A. euteiches & Ae186 & France (Brittany) & ND & + & 108 \\
\hline A. euteiches & Ae187 & France (Normandy) & ND & + & 80 \\
\hline A. euteiches & Ae190 & France (Rhône-Alpes) & ND & + & 122 \\
\hline A. euteiches & Ae193 & France (Rhône-Alpes) & ND & + & 61 \\
\hline A. euteiches & Ae196 & France (Rhône-Alpes) & ND & + & 121 \\
\hline A. euteiches & Ae197 & France (Rhône-Alpes) & ND & + & 97 \\
\hline A. euteiches & Ae200 (GAE-Pep) & France (Brittany) & ND & + & 97 \\
\hline
\end{tabular}

${ }^{a}$ A. euteiches isolates from different locations worldwide have been successfully amplified with specific primers designed in this study.

b ND stands for not determined.

c Internal transcribed spacer 1 (ITS1) copy number for each isolate is reported (see results for details). 
cell suspension was centrifuged at $1,500 \times g$ for $30 \mathrm{~s}$, and $3 \mathrm{ml}$ of supernatant was removed and discarded using a pipette. Concentrated cell suspension was then centri-filtered at 2,500 $\times g$ for $4 \mathrm{~min}$ through CellTrics (30 $\mu \mathrm{m}$, Partec GmbH, Münster, Germany), and oospores were counted on a hemocytometer. Oospore suspension could be kept at $4^{\circ} \mathrm{C}$ for 2 to 3 days without impairing their germination capacity (not shown).

Soil inoculations. Three luvisoils from Normandy (France) were selected based on two criteria: the organic matter content or the presence of susceptible plants for A. euteiches in the cropping history. Three independent surface soil samples were taken from each plot. Each sample was made up by pooling and gently mixing nine cores taken within a 1-m-diameter circle from the top layer. Soil samples were immediately placed in a coolbox until the return to lab. Standard soil analyses (texture, $\mathrm{pH}$, total carbon and total nitrogen, and organic matter) were performed using standard methods as described in Forster (16). Calcium content determination was performed following the international standard NF X31-108 (2002). Soil gravimetric water contents were determined after oven drying at $105^{\circ} \mathrm{C}$ for $24 \mathrm{~h}$. Soil characteristics and cropping history are summarized in Table 2.

Soils were used raw or sterilized, after three 24-h-spaced sterilizations by autoclaving $\left(121^{\circ} \mathrm{C}, 20 \mathrm{~min}\right)$, sieved for $2 \mathrm{~mm}$, and stored at $4^{\circ} \mathrm{C}$ until use. Water holding capacity (WHC) was determined by the methodology described by Cassel and Nielsen (12). For inoculation with oospores, $50 \mathrm{~g}$ of soil from each field sample was dispensed in 180-ml specimen containers. Oospore suspensions were diluted in sterile water (or only sterile water for control) in order to comply with a $70 \%$ soil WHC and extensively mixed with soil with a laboratory spatula. For the evaluation of efficiency, sensitivity, and accuracy of the quantification molecular assay, oospore suspensions containing 10, 100, or 1,000 oospores per $\mathrm{ml}$ from the two isolates Ae22 and Ae84 (Table 1) were used. Oospore suspensions from A. cladogamus and A. cochlioides were used as negative controls (Table 1). For the evaluation of the relationship between IP and number of oospores, 10-fold dilutions of noncalibrated oospore suspension from both Ae22 and Ae84 isolates were used. All experiments were repeated twice.

Determination of the IP of soils. According to the experimental design described above, IPs of soil were determined according to Moussart et al. (35) except for soil quantities (50 g was used rather than $500 \mathrm{ml}$ ). Briefly, for each $180-\mathrm{ml}$ specimen container (three per treatment) containing $50 \mathrm{~g}$ of soil, three pea seeds (cultivar Baccara) were sown. Containers were placed for 14 days in a climatic chamber at $24^{\circ} \mathrm{C}$ and $80 \%$ humidity with a photoperiod of 16-h light/8-h dark. After a careful washing of roots under running tap water, IP was determined after a visual assessment of root symptoms according to Wicker at al. (57). IP was evaluated on a scale from 0 to 5 , where $0=$ no symptom; $1=$ roots with a few small honey-colored lesions; $2=$ less than $90 \%$ of the root system is honey-colored; $3=$ more than $90 \%$ of the root system is brown but epicotyl or hypocotyl is still healthy; $4=$ $100 \%$ of the root system is brown and hypocotyl or epicotyl is softened or brown; and $5=$ dead plant (45).

DNA extraction and quantification from soil. From each specimen container, total soil DNA was extracted from $0.5 \mathrm{~g}$ of moist soil using the Fast DNA spin Kit for Soil (MP-Biomedicals, Santa Ana, CA). DNA was resuspended in sterile molecular biology grade water to give a final volume of $50 \mu \mathrm{l}$. Purified DNA was quantified by fluorimetry using the Fluorescent DNA quantitation Kit (Hoechst 33258, Bio-Rad, Hercules, CA) for concentrations over $5 \mathrm{ng} \mathrm{\mu l}^{-1}$ or the Quant-iT dsDNA Broad-Range Assay Kit (Picogreen, Life Technologies, Carlsbad, CA) for con-

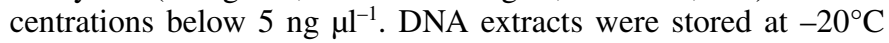
until further use.

A. euteiches primers design. In order to ease the quantification of low inoculum levels, high-copy-number ITS1 sequences from rDNA were targeted in A. euteiches genome. Forty-three ITS1 sequences from Aphanomyces from plant-parasitic lineage (14) were downloaded from GenBank and consensus sequence(s) were determined from each of the four species by removing redundancies. Those consensus sequences were aligned using T-coffee (36). Similarity percentages were acquired using Blastn (61), and cladogram tree was generated using clustal-W2-Phylogeny suite. Primers were designed so that the nucleotides unique to A. euteiches should be at the $3^{\prime}$ end of each primer and that the length of the PCR products should not exceed $200 \mathrm{bp}$.

Copy number of ITS1 from rDNA per A. euteiches genome. The number of copies of rDNA repeat units was estimated by the comparison of the cycle thresholds obtained for ITS1 primers and a single-copy sequence (44) named ' 76 bp' by Vandemark et al. (54). Four log-decimal dilutions of the genomic DNA extracted from each strain of A. euteiches listed in Table 1 were used. For both primer sets, qPCR amplifications were performed in a total volume of $50 \mu \mathrm{l}$. The qPCR mix was prepared as follows: $25 \mu \mathrm{l}$ of Power SyBrGreen PCR master MIX (Life Technologies), $0.5 \mathrm{mg}$ $\mathrm{ml}^{-1}$ BSA (NEB, Ipswich, MA), $1.5 \mathrm{mM} \mathrm{MgCl}_{2}, 4 \mu \mathrm{g} \mathrm{ml}{ }^{-1}$ ETSSB (NEB), and $12.5 \mathrm{pmol}$ of each primer (Ae_ITS1_39F [ $5^{\prime}-$ TGAGGCTTGTGCTCTTTTCA-3'] and Ae_ITS1_167R [5'-GA AAGTTGTATAGAATTGACAAGCT-3']) or (Ae76bp_136_F [5'-

TABLE 2. Main characteristics of soils sampled

\begin{tabular}{|c|c|c|c|c|c|c|c|c|c|c|c|c|c|c|}
\hline \multirow[b]{2}{*}{ Code } & \multirow[b]{2}{*}{ Use } & \multirow[b]{2}{*}{$\begin{array}{l}\text { Geographic } \\
\text { coordinates }\end{array}$} & \multicolumn{4}{|c|}{ Texture } & \multicolumn{8}{|c|}{ Physico-chemistry } \\
\hline & & & $\begin{array}{l}\text { Clay } \\
(\%)\end{array}$ & $\begin{array}{l}\text { Silt } \\
(\%)\end{array}$ & $\begin{array}{c}\text { Sand } \\
(\%)\end{array}$ & Type & $\mathrm{pH}$ & $\begin{array}{c}\mathrm{C} \\
\left(\mathrm{mg} \mathrm{g}^{-1}\right)\end{array}$ & $\begin{array}{c}\mathrm{N} \\
\left(\mathrm{mg} \mathrm{g}^{-1}\right)\end{array}$ & $\mathrm{C} / \mathrm{N}$ & $\begin{array}{c}\mathrm{Ca} \\
\left(\mathrm{mg} \mathrm{g}^{-1}\right)\end{array}$ & $\begin{array}{c}\mathrm{OM} \\
\left(\mathrm{mg} \mathrm{g}^{-1}\right)\end{array}$ & $\begin{array}{c}\mathrm{W}_{\mathrm{H} 20} \\
(\%)\end{array}$ & $\begin{array}{c}\text { WHC } \\
(\%)\end{array}$ \\
\hline TOPP & Pasture & $\begin{array}{l}49^{\circ} 10.676^{\prime} \mathrm{N} \\
1^{\circ} 32.830^{\prime} \mathrm{E}\end{array}$ & 16 & 61 & 23 & Silty loam & 6.6 & 30.6 & 2.7 & 11.5 & 736 & 77.8 & 21.1 & 32.6 \\
\hline TOGC & Polyculture & $\begin{array}{l}49^{\circ} 10.959^{\prime} \mathrm{N} \\
1^{\circ} 33.562^{\prime} \mathrm{E}\end{array}$ & 18 & 69 & 13 & Silty loam & 7.8 & 10.8 & 1.1 & 10.2 & 989 & 36.5 & 25.3 & 32.8 \\
\hline GUGC & Polyculture & $\begin{array}{l}49^{\circ} 12.449^{\prime} \mathrm{N} \\
1^{\circ} 32.393^{\prime} \mathrm{E}\end{array}$ & 19 & 72 & 9 & Silty loam & 7.3 & 11.6 & 1.1 & 10.2 & 767 & 42.7 & 20.4 & 32.1 \\
\hline
\end{tabular}

\begin{tabular}{|c|c|c|c|c|c|c|c|c|c|c|}
\hline \multirow[b]{2}{*}{ Code } & \multicolumn{10}{|c|}{ Cropping history } \\
\hline & 2003 & 2004 & 2005 & 2006 & 2007 & 2008 & 2009 & 2010 & 2011 & 2012 \\
\hline TOPP & \multicolumn{10}{|c|}{ 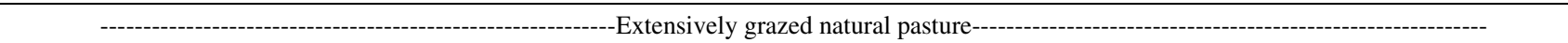 } \\
\hline TOGC & Winter barley & Alfalfa & Alfalfa & Wheat & Sugar beet & Wheat & Ryegrass & Pea & Wheat & Rapeseed \\
\hline GUGC & Flax & Sugar beet & Wheat & Sugar beet & Rapeseed & Wheat & Potato & Wheat & Sugar beet & Wheat \\
\hline
\end{tabular}


GACTGCAATGTCGTCCAAGACTT-3'] and Ae76bp_211_R [5'-ACAAAGCTGAGATGAAGAGATCGA-3']). qPCR mixes were the same for each strain for both sets of primers, and amplifications were carried out in the same 96-well microplate. After an initial denaturation and enzyme activation step of $10 \mathrm{~min}$ at $95^{\circ} \mathrm{C}, 45$ cycles of PCR were performed in the 7300 real-time PCR System (Applied Biosystems, Foster City, CA) as follows: $30 \mathrm{~s}$ at $95^{\circ} \mathrm{C}, 30 \mathrm{~s}$ at $60^{\circ} \mathrm{C}$, and $30 \mathrm{~s}$ at $72^{\circ} \mathrm{C}$. Upon PCR completion, melting curve analysis was used to determine whether there was detectable primer-dimer contribution to the SYBRGreen fluorescence measurement. The efficiency of qPCR ranged from 86 to $118 \%$ for ITS1 and from 81 to $125 \%$ for ' 76 bp'. The copy number of ITS1 $\left(\mathrm{N}_{\text {ITS1 }}\right)$ for each strain was calculated using the following formula: $\mathrm{N}_{\mathrm{ITS} 1}=(1+\varepsilon)^{\mathrm{Ct}}\left(1+\varepsilon^{\prime}\right)^{\mathrm{Ct}^{\prime}}$, where $\varepsilon$ and $\varepsilon^{\prime}$ are the qPCR efficiencies calculated for ITS1 primers and ' 76 bp' primers, respectively. $\mathrm{Ct}$ and $\mathrm{Ct}^{\prime}$ were the cycle thresholds determined from the same threshold line for qPCR with ITS1 primers or ' 76 bp' primers, respectively. Results are expressed as average \pm standard deviation determined after three independent experiments.

Field soil quantification of $A$. euteiches by qPCR targeting ITS1 sequences. A. euteiches ITS1 amplifications were carried out as above except for the amount of DNA per reaction that was standardized to $1 \mathrm{ng}$ or $125 \mathrm{pg}$ for sterilized soils. Dilution series containing known amounts of A. euteiches Ae200 (Table 1) genomic DNA were used as the standard for quantification of dsDNA sample. The absence of qPCR inhibition by possible soil contaminants was verified by comparison of $\mathrm{Ct}$ and efficiency of qPCR with or without addition of soil extracts exempt from A. euteiches targets (not shown). Results are expressed as the number of pathogenic units (oospores) per gram of dry soil assuming that the A. euteiches $\mathrm{C}$-value is $50 \mathrm{Mb}$ (3).

Statistics. Depending on the case, medians and/or arithmetic means \pm standard deviations of triplicate analysis of samples are presented. The goodness of fit of the ITS1 copy number distribution was assessed by the Shapiro-Wilk test after determination of the optimal number of bins following the Sturges' rule (33). The shape of the normal distribution was described by skewness and kurtosis. For the test of efficiency, sensitivity and accuracy of the qPCR method in field soils, analysis of Pearson product- moment correlation coefficients (PPMCC), and analysis of variances (ANOVAs) were carried out. When requirements for oneway ANOVAs were not met (i.e., variances were different), multiple comparisons were performed using a Kruskal-Wallis test. In both tests, the significance level was $P=0.05$. Simple regression analyses were conducted to evaluate the relationship between the IP of field soils and the log-transformed number of pathogenic units per gram of dry soil. For each regression analysis, $P$ values are indicated in figure captions. Finally, Wilcoxon matched pairs signed-ranks tests were used to evaluate the significance of difference observed for the comparison of the relationship between IP and the number of oospores per gram of dry soil in sterilized or raw soils. These analyses were all conducted using XLSTAT-Pro v6.0 (Addinsoft, Paris, France).

\section{RESULTS}

ITS1 from rDNA operon presents only few sequence variations among the Aphanomyces plant-parasite lineage. The alignment of the five ITS1 consensus sequences derived from the 43 Aphanomyces $\mathrm{rDNA}$ sequences belonging to the plant-parasite lineage available in GenBank confirmed the homology between A. cladogamus, A. cochlioides, A. iridis, and A. euteiches (Fig. 1A). Similarity of sequences ranged from $77 \%$ between A. cladogamus and A. euteiches 2 to $93 \%$ between A. iridis and A. euteiches 1 (Fig. 1B). For the last two species, only a single nucleotide (in position 57) made the difference inside ITS1 sequences (Fig. 1A). Cladogram constructed from the pairwise comparisons of the five ITS1 consensus sequences (Fig. 1) drew three clusters consisting of the A. euteiches branch in which consensuses differed by a $19 \mathrm{bp}$ insertion, the A. iridis branch closely related to A. euteiches and a third more distant branch involving A. cladogamus and A. cochlioides.

Primer design and their specificity toward A. euteiches. Different sets of primers targeting the most dissimilar sequences between the plant-parasitic Aphanomyces have been designed by varying length and/or location of primers. Every combination has been tested before finding the best scheme (not shown), leading to a 129 or 148 bp amplicon depending on the A. euteiches ITS1 sequence consensus considered (Fig. 1). Ae_ITS1_39F ends on
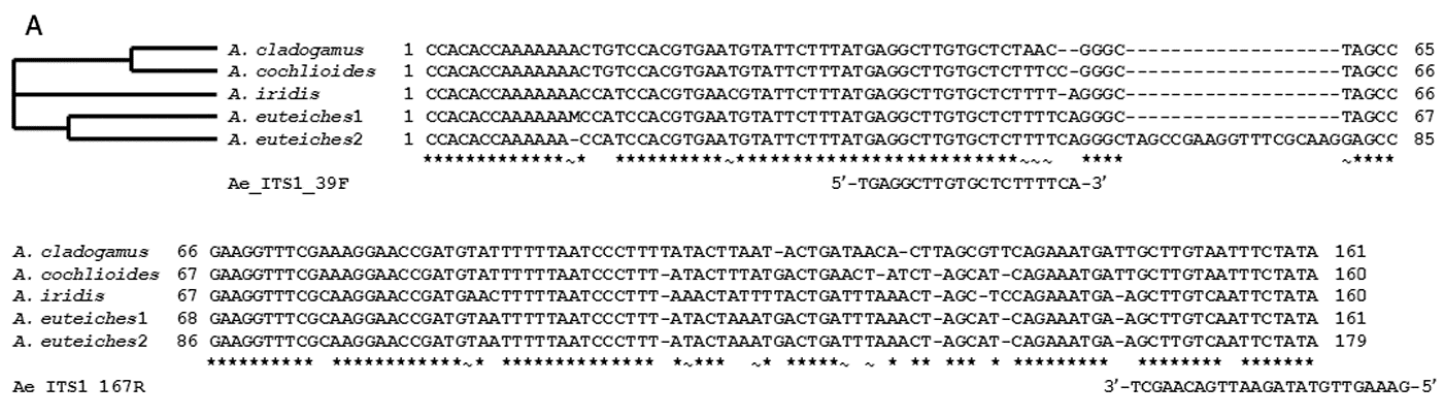

Ae_ITS1_167R

$3^{\prime}$-TCGAACAGTTAAGATATGTT GAAAG- $5^{\prime}$

B

$\begin{array}{cccccc} & \text { A.cladogamus } & \text { A. cochlioides } & \text { A. iridis } & \text { A. euteiches1 } & \text { A. euteiches2 } \\ \text { A.cladogamus } & 100 \%(0) & & & & \\ \text { A. cochlioides } & 92 \%(0.119) & 100 \%(0) & & & \\ \text { A. iridis } & 84 \%(0.201) & 86 \%(0.190) & 100 \%(0) & & \\ \text { A. euteiches1 } & 85 \%(0.223) & 90 \%(0.184) & 93 \%(0.081) & 100 \%(0) & \\ \text { A. euteiches2 } & 77 \%(0.247) & 80 \%(0.210) & 83 \%(0.113) & 89 \%(0.031) & 100 \%(0)\end{array}$

Fig. 1. Sequence similarities of internal transcribed spacer 1 (ITS1) from rDNA among Aphanomyces plant-parasitic species. A, Aphanomyces plant-parasitic lineage phylogeny. Sequences from A. cladogamus, A. cochlioides, A. iridis, and A. euteiches were downloaded from GenBank and aligned using "T-coffee." Redundant or misidentified sequences were removed, leading to one consensus for each species except $A$. euteiches for which two consensus sequences were revealed. The number of sequences retained for each consensus is 11 for A. cladogamus, 13 for A. cochlioides, 2 for A. iridis, 15 for A. euteiches 1 , and 2 for A. euteiches2. Cladogram tree was generated using the "Clustal W2 Phylogeny" suite. Primers Ae_ITS1_39F and Ae_ITS1_167F, shown below, are aligned with ITS1 sequences. B, Table of similarity percentages and indexes between Aphanomyces plant-parasitic species. Similarity indexes are indicated between brackets. 
the single nucleotide differing between $A$. euteiches and A. iridis. Ae_ITS1_167F had to be extended to 25 mer at $5^{\prime}$ end in order to raise its melting temperature $\left(\mathrm{T}_{\mathrm{m}}\right)$ to gain compatibility with the $\mathrm{T}_{\mathrm{m}}$ of Ae_ITS1_39F.

Those primers allowed the actual amplification of the 40 A. euteiches isolates available and there was no amplification for A. cladogamus or A. cochlioides (Table 1). The analysis of dissociation curves after amplification allowed verifying the existence of two PCR products corresponding to the two consensuses for $A$. euteiches ITS1 sequence with melting temperatures equal

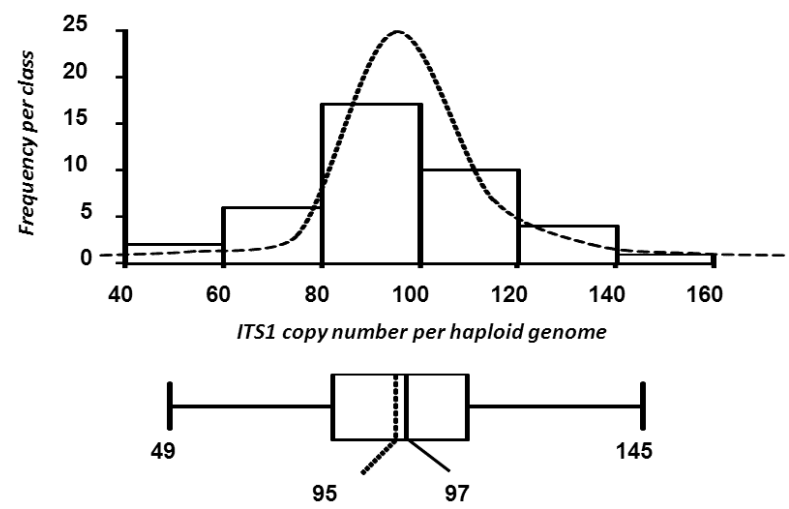

Fig. 2. Repartition of internal transcribed spacer 1 (ITS1) copy numbers per haploid genome for 40 Aphanomyces euteiches isolates. For each isolate, the number of copy of ITS1 per haploid genome was estimated by the comparison of cycle threshold and efficiency for a single-copy sequence or ITS1. The dashed line bell curve was drawn after testing the normal distribution of values by the Shapiro-Wilk test. Minimum value $(\vdash)$, maximum value $(\dashv)$, second quartile ([), third quartile (]), median (plain bar), and mean (dotted bar) are shown in the box plot $(n=40)$. to $74.3^{\circ} \mathrm{C}$ for $A$. euteiches 1 and $76.9^{\circ} \mathrm{C}$ for A. euteiches 2 (not shown). That double peak was observed for all isolates proving the coexistence of both consensuses in A. euteiches genome. Moreover, the contribution of each peak in SyBrGreen fluorescence was similar whatever the isolate.

ITS1 copy number per $A$. euteiches haploid genome. The number of ITS1 copy for A. euteiches ranged from 49 to 145 per haploid genome with a median value of 97 and a mean value of $95 \pm 22$ ITS1 per haploid genome (Table 1; Fig. 2). Variations in the number of ITS1 per genome for each of three analytical repetitions per isolate were always lower than 2 (not shown). The numbers of ITS1 were normally distributed according to the Shapiro-Wilk test $(P=0.05)$ with skewness $=-0.23$ and kurtosis $=$ -0.05 (Fig. 2).

There was no significant relationship $(P>0.1)$ between the copy number of the ITS1 sequence and any descriptive variable for isolates (sampling site in France or worldwide, virulence) demonstrating the unpredictable nature of this trait from the data gathered from those isolates.

Efficiency, sensitivity, and accuracy of the method in field soils. The number of diploid genome quantified by qPCR targeting ITS1 sequences fitted the amount of A. euteiches oospores spiked in field soils (Table 3), with PPMCC over 0.999 whatever the treatment (soil type, soil sterilization, A. euteiches isolate). ANOVA between those treatments did not show any significant difference. For the three soils assessed, the quantification method for A. euteiches proved to be accurate and efficient even with low inoculums (10 oospores per gram of dry soil). Coefficients of variation $(\mathrm{CV})$ ranged from $0.5 \%$ for the raw soil from TOPP inoculated with 1,000 oospores per gram of dry soil to $78.6 \%$ for the raw soil from GUGC inoculated with 10 oospores per gram of dry soil. Median CV values for inoculums of 10, 100, or 1,000 oospores per gram of soil were 20,26, and $46 \%$, respectively, and

TABLE 3. Aphanomyces euteiches genome recovery after artificial inoculation ${ }^{\mathrm{a}}$

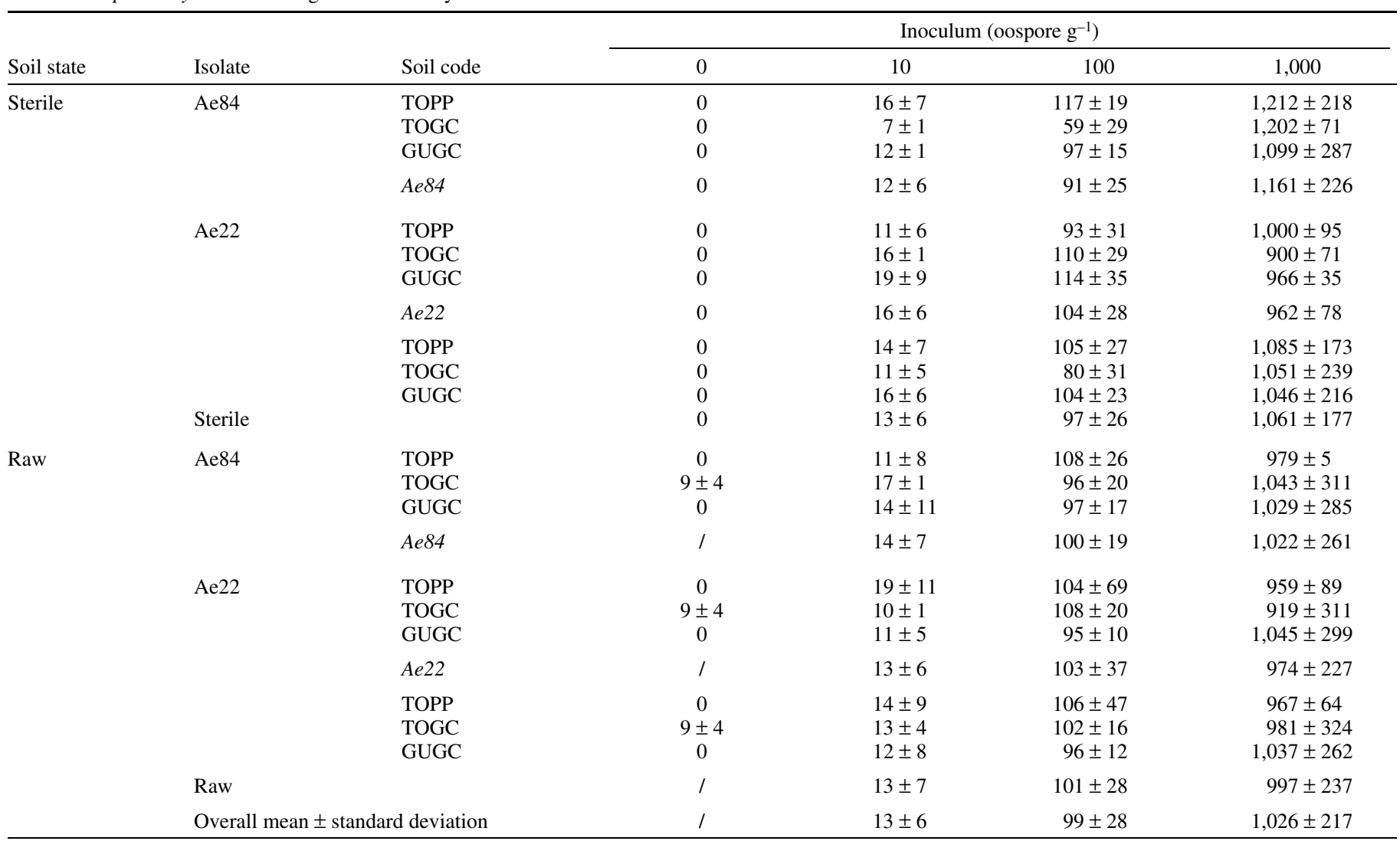

${ }^{a}$ Three types of soil sterilized or not (raw) were inoculated with oospores from two A. euteiches isolates with low or high virulence (I for Ae22 or X for Ae84). The number of diploid genome recovered was determined after quantitative polymerase chain reaction targeting the internal transcribed spacer region in $A$. euteiches genome. Results are expressed as mean \pm standard deviation. 
$\mathrm{CV}$ calculated from the full data set for each inoculum size were 21,28 , or $46 \%$, respectively. As suspected, field soil from TOGC actually contained $A$. euteiches oospores $(9 \pm 4$ per gram of dry soil) due to a former pea crop infestation by this oomycete in 2010 (Table 2).

Relationship between IP and oospore density quantified by qPCR. The intensity of pea root symptoms due to A. euteiches proved to be strongly dependent upon the amount of pathogenic units in raw field soils (Fig. 3) with a coefficient of determination $R^{2}=0.911(R=0.955)$ and a $P$ value $<10^{-4}$. The relationship between IP and the number of oospores per gram of dry soil should thus be described by the following formula: IP $=0.176+$ $1.245 \times \log$ (oospore $\mathrm{g}^{-1}$ of dry soil). As previously demonstrated for the assessment of the efficiency, accuracy, and sensitivity of the molecular method, neither soil characteristics nor A. euteiches isolate influenced this relationship (with a Type 1 error $(\alpha)=0.5$ ).

Impact of soil sterilization on the IP. Relationship between the number of oospores per gram of soil and the IP were analyzed for each soil sampling site, focusing on the influence of soil sterilization on the level of pea root symptoms (Fig. 4). For TOPP, raw soils led to a significant rise of IP in comparison with sterilized soil, for A. euteiches oospore density over approximately 50 oospores per gram of dry soil (Fig. 4A). On the contrary, root rot was significantly more severe in sterilized soil from TOGC than in raw soil for an equal pathogenic unit density, even for low inoculums (Fig. 4B). Finally, soil sterilization had no effect on the relationship between IP and the density of $A$. euteiches oospores for GUGC (Fig. 4C). Taken together, those results demonstrate a differential influence of the soil microbiota which appears to modulate the amount of symptoms observed for a given density of pathogenic units, depending on the origin of soils. Whatever the soil provenance or treatment (raw versus sterilized), the opposite virulence of Ae22 and Ae84 isolates did not exert any significant influence on IP, according to what was expected with susceptible pea cultivar Baccara.

\section{DISCUSSION}

Comparative analysis of Aphanomyces ITS1 sequences from the plant-parasitic lineage. A. euteiches genome has not been sequenced yet and little is known about Aphanomyces genetics. So, when envisaging a molecular test targeting specific sequences from this oomycete, the pool of sequences available were insufficient. Moreover, designing a molecular assay for a matrix as complex as soil leads to a preference for multicopy targets in order to gain sensitivity. In this context, ribosomal DNA operon sequences appear to be the most suitable target for this kind of approach. Indeed, those sequences are now widely used for the quantification of different microorganisms including phytopathogens $(4,23,52,59)$. Most studies target the ITS regions which consist of the most variable sequences inside rDNA operons from closely related species. Sequence comparisons inside the genus Aphanomyces have already been fully studied by DiéguezUribeondo et al. (14) and especially for the plant pathogen lineage consisting of four species (A. cladogamus, A. cochlioides, A. iridis, and A. euteiches). More recently, Robideau et al. (43) supplied a large set of sequences leading to reconsider the phylogeny of Aphanomyces plant pathogens (Fig. 1). Thus, A. iridis, formerly considered by Diéguez-Uribeondo et al. (14) as a Japanese specific $A$. euteiches variant, should now be considered as a species on its own, since the gene encoding cytochrome $\mathrm{c}$ oxidase subunit I (COXI) from A. iridis and A. cochlioides are more closely related than those from A. iridis and A. euteiches (43). Moreover, Robideau et al. (43) sequenced a new variant for A. euteiches ITS1 sequence which includes a 19-bp insertion consisting of an exact direct tandem repeat of the sequence located immediately after the insertion point. Interestingly, this 19-bp sequence appears as a common feature of Saprolegnaceae (blastn [61]). Nevertheless, A. euteiches is the only species among this family bearing this direct tandem repeat inside ITS1. For many species, sequence variations in ITS1 have already been fully described between individuals or even inside a single multicellular organism, but the kind of specific segmental duplication observed remains undescribed.

Primer design for A. euteiches and preference for the SyBrGreen chemistry qPCR. Given the weak differences observed between the Aphanomyces species belonging to the plant pathogen lineage and taking into account the specific $A$. euteiches ITS1 sequence duality, the choice for specific primers for this oomycete was restricted to the most dissimilar regions among the

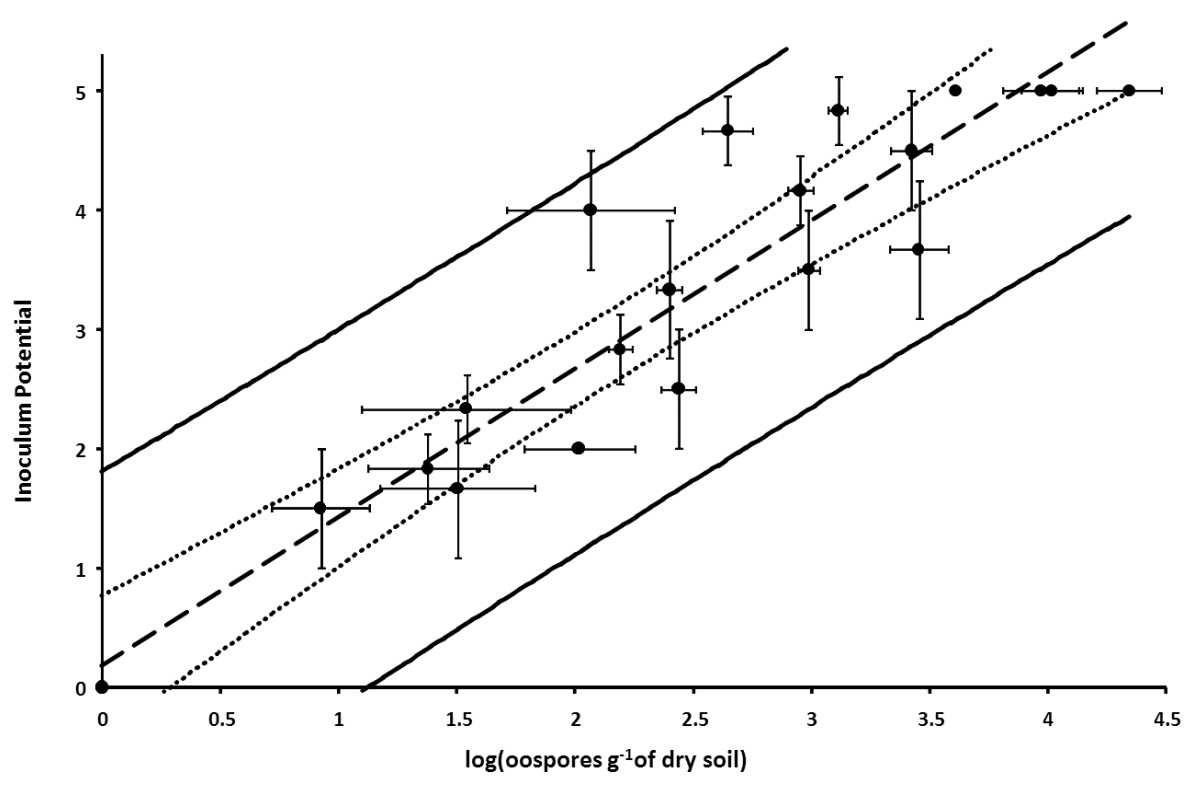

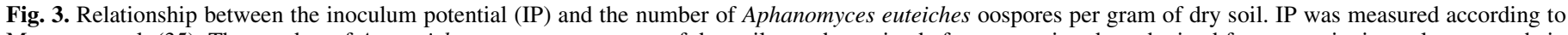

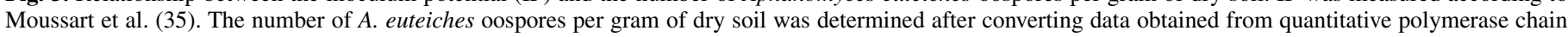

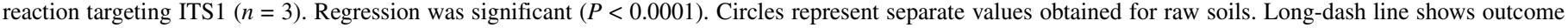

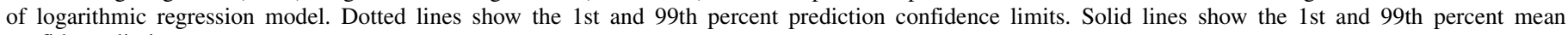
confidence limits. 
species considered from either sides of the insertion. Among the numerous pairs of primers tested for their specificity toward $A$. euteiches or intrinsic properties, Ae_ITS1_39F and Ae_ITS1_167R showed the best compromise ( $\mathrm{T}_{\mathrm{m}}$, specificity, sensitivity). Validations of those primers were both tested by in vitro experimentation with different $A$. euteiches isolates or other Aphanomyces species (A. cladogamus and $A$. cochlioides) and by blasting each primer sequence against GenBank. The assignment of A. iridis inside the $A$. euteiches species by Diéguez-Uribeondo et al. (14) and the narrow host range, restricted to the genus Iris, described by Ichitani et al. (25) for this plant pathogen led us to consider that it was superfluous to test the specificity of our ITS1 primers for this species. Given this study and the data supplied recently by Robideau et al. (43), it may now seem scientifically pertinent to test the specificity of the molecular test with A. iridis

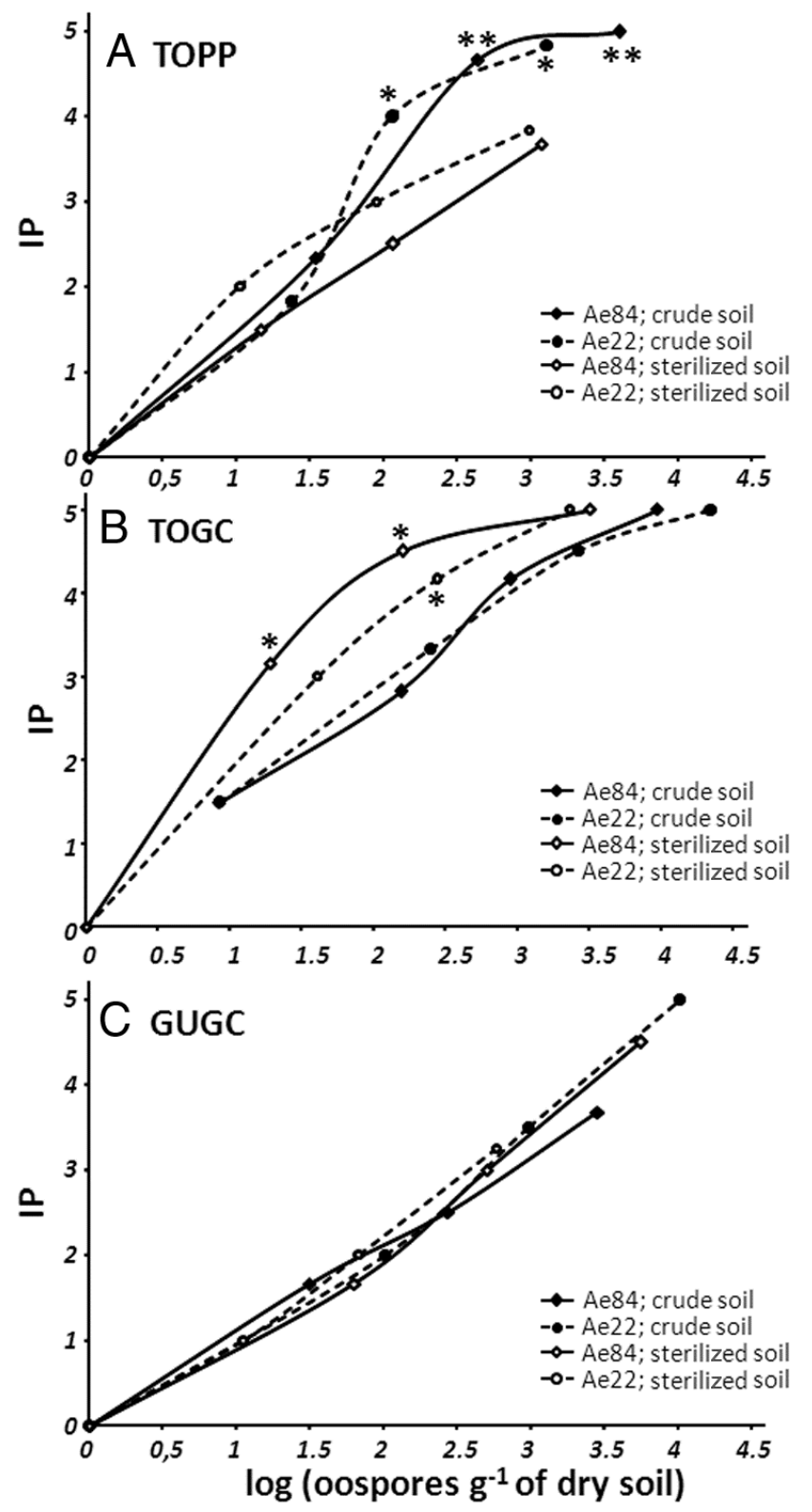

Fig. 4. Effects of soil sterilization on the relationship between inoculum potential (IP) and the number of Aphanomyces euteiches per gram of dry soil. A, TOPP; B, TOGC; C, GUGC. Correspondences between IP and the number of A. euteiches per gram of dry soil. Solid and dashed lines show values obtained for Ae84 or Ae22 isolates, respectively. Open circles or diamonds represent values obtained for sterilized soils. Plain circles or diamonds represent values for raw soils $(n=3)$. ${ }^{*}$ indicates significant at $P<0.05$; and ** indicates significant at $P<0.005$ when its ITS1 sequence only diverges from A. euteiches 1 consensus by 1 bp located at the $5^{\prime}$ end of Ae_ITS1_39F. However, since 1986, A. iridis has never been isolated elsewhere other than in the Nara prefecture in Japan; therefore, the probability of finding A. iridis in field soils could be considered highly unlikely.

Finally, attempts for a TaqMan assay more commonly recommended for this kind of quantification (47) did not encounter success mainly because the ITS1 region between primers is ATrich $(66 \%$ AT) and thus did not allow the design of a probe with a $\mathrm{T}_{\mathrm{m}}$ compatible with those of primers. Furthermore, given the high sequence similarity inside this region for the four Aphanomyces species, it was impossible to design a hybridization probe specific for A. euteiches.

Variations in the ITS1 copy number among A. euteiches isolates. Because ITS1 region is a multicopy target in genome, great gains in sensitivity should be obtained compared with singlecopy sequences. However, a qPCR assay based on ITS1 sequences should rely on a constant number of copies for each isolate and between isolate. A large panel consisting of 40 isolates from different locations worldwide was used to analyze the variability of ITS1 copy number in A. euteiches genome. The range of ITS1 copy number obtained in this study may question the reliability of the method of quantification of A. euteiches depending on the isolate but similar results were obtained by Bilodeau et al. (4) when they estimated the intergenic region copy number in Verticillium dahliae genome. Besides, variations in rDNA copy number have been reported for many species and especially in fungi $(1,4,32,41)$. The regulation mechanisms of the number of copies of rDNA per genome for a single isolate have been described for numerous species and are well known in yeasts in particular $(22,30)$.

Nevertheless, the ITS1 region copy number was normally distributed allowing for the prediction of the margin of error of any $A$. euteiches quantification by the molecular method proposed in this study. For instance, $68 \%$ of values will lie between 73 and 116 ITS1 copy number leading to an error margin below $23 \%$. In the same way, $95 \%$ of values will lie between 54 and 146 ITS1 copy number for an error margin below 52\%. Interestingly, raising the number of characterizations of rDNA copy number for isolates allowed a gain in precision as kurtosis always increased when new data were acquired. As geographical origin of isolates could not be considered as a decisive factor in order to explain the variability in the number of ITS 1 per genome, only a better knowledge of $A$. euteiches genetics may be considered as a means in the understanding of those variations.

Accuracy of predictive methods is governed by soil sampling, especially for low inoculums. The major concern when trying to predict soil characteristics, and in particular IP as defined by Moussart et al. (35) for A. euteiches, from soil samples lies in the representativeness of the sampling. In this study, soils were artificially inoculated with known amounts of A. euteiches pathogenic units purified by a new method which allowed us to obtain pure oospore suspensions. However, even after harsh mechanical homogenization, sampling of only $1 \%$ of inoculated soil $(0.5 \mathrm{~g})$ for DNA extraction for each repetition led to somewhat considerable coefficients of variation (CV) in A. euteiches quantifications which were lower for high inoculums. Nevertheless, despite those $\mathrm{CV}$, molecular quantifications of pathogenic units were always statistically in accordance with the number of oospores artificially inoculated whatever the treatments (soil properties or A. euteiches isolate). Obviously, soil sampling strategy remains the most critical component governing the reliability of any plant disease potential test. Similar to other soilborne diseases, pea root rot due to A. euteiches appears in clusters as disease foci (35) and sampling strategies may lead to false negative or overestimated level of predicted symptoms at a field scale. Thus, one of the greatest challenges for soil-pathogenic microorganism assays remains the modeling of field soil patho- 
gens scattering. Be that as it may, qPCR quantification of soilborne plant pathogens based on the amplification of ITS1 is becoming the leading method for predicting plant pathologies with high sensitivity $(4,23,59)$.

Relationships between IP and the amount of A. euteiches pathogenic units quantified by qPCR-Modeling pea yield loss? A former study by Sauvage et al. (44) allowed the establishment of a logarithmic relationship between IP and A. euteiches oospore density in field soils determined by a qPCR assay which could be transcribed as IP $=0.223+1.105 \times \log \left(\right.$ oospore $\mathrm{g}^{-1}$ of dry soil). However, this qPCR method targeting a single-copy gene did not allow quantification of $A$. euteiches oospore densities under 200 oospores per gram of dry soil. With an average of 95 ITS 1 copy number within a single haploid genome and because A. euteiches is mainly diploid along its life cycle, theoretical detection threshold should be around 1 oospore $\mathrm{g}^{-1}$ of dry soil and may lead to a generalization of the previous model for low inoculums. As a matter of fact, IP and the number of $A$. euteiches pathogenic units observed in this study were causally related for inoculums as low as about 10 oospores $\mathrm{g}^{-1}$ of dry soil. IP measurement after direct spiking of low density oospore suspensions in soil by Persson et al. (38) also concluded a logarithmic relationship between IP and the number of A. euteiches oospores per gram of dry soil that can be represented by the following formula: IP $=-1.041+1.531 \times \log \left(\right.$ oospore $\mathrm{g}^{-1}$ of dry soil $)$. The comparative representation of the three models $(38,44$, and this study) describing the relationships between IP and the number of

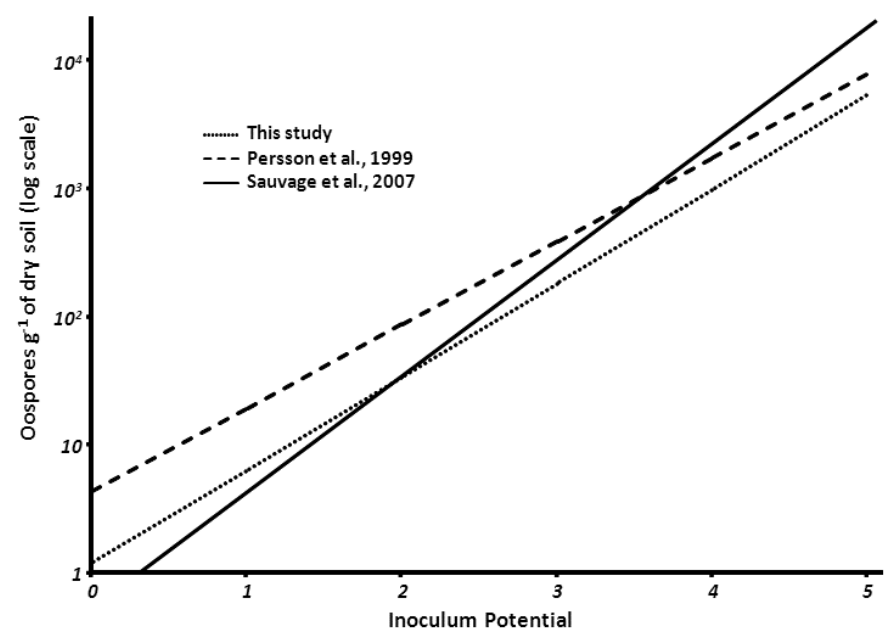

Fig. 5. Graphical comparisons of three models describing the relationship between inoculum potential (IP) and the number of Aphanomyces euteiches oospores per gram of soil. The model obtained in this study [IP $=0.176+$ $1.245 \times \log \left(\right.$ oospore $\mathrm{g}^{-1}$ of dry soil $\left.)\right]$, by Sauvage et al. (44) $[\mathrm{IP}=0.223+$ $1.105 \times \log \left(\right.$ oospore $\mathrm{g}^{-1}$ of dry soil $\left.)\right]$, or by Persson et al. (38) $[\mathrm{IP}=-1.041+$ $1.531 \times \log \left(\right.$ oospore $\mathrm{g}^{-1}$ of dry soil $\left.)\right]$ are plotted.

TABLE 4. Comparisons of three models describing the relationship between inoculum potential (IP) and the number of oospores per gram of soil ${ }^{\mathrm{a}}$

\begin{tabular}{lccc}
\hline \multicolumn{3}{c}{ Oospores g $^{-1}$ of dry soil } \\
\cline { 2 - 4 } IP & Sauvage et al. (44) & Persson et al. (38) & This study \\
\hline 1 & 5 & 22 & 5 \\
2 & 41 & 97 & 29 \\
3 & 326 & 436 & 185 \\
4 & 2,619 & 1,962 & 1,179 \\
5 & 21,042 & 8,826 & 7,494 \\
\hline
\end{tabular}

a A prediction of the number of oospores per gram of dry soil for given IP was calculated according to the model obtained in this study [IP $=0.176+1.245$ $\times \log \left(\right.$ oospore $\mathrm{g}^{-1}$ of dry soil)], by Sauvage et al. (44) $[\mathrm{IP}=0.223+1.105 \times$ $\log \left(\right.$ oospore $\mathrm{g}^{-1}$ of dry soil) $]$ or by Persson et al. (38) $[\mathrm{IP}=-1.041+1.531 \times$ $\log \left(\right.$ oospore $\mathrm{g}^{-1}$ of dry soil)].
A. euteiches oospores (Fig. 5) leads to fitness of the data. Unfortunately, without the overall data for each model, it was not possible to statistically test the correspondence between them. As a guide for a more precise appreciation of an order of magnitude for each logarithmic relationship, Table 4 depicts the evaluation of the number of pathogenic units for a given IP for each model. Interestingly, the relationship between IP and the A. euteiches soil density demonstrated in this study appears congruent with the one proved by Sauvage et al. (44) for IP below 2 and with the one proved by Persson et al. (38) for IP over 4. Notwithstanding, the consensual model proposed in this study will require a large amount of data before it may be considered as canonical.

Soil receptivity toward $A$. euteiches. While reducing the use of pesticide has become a huge challenge for society, the knowledge of factors governing the emergence of phytopathogens is becoming crucial in the management of plant diseases. As a matter of fact, little is known about the soil factors influencing pea root rot due to A. euteiches and two paradigms are in confrontation concerning this specific pathogen. Oyarzun et al. (37) described the behavior of $A$. euteiches to be insensitive to changes in soils characteristics, whereas Persson et al. (38) demonstrated the influence of abiotic soil parameters on disease by showing the suppressive effect of draining soils (39) or increasing high $\mathrm{Ca}^{2+}$ concentrations (21). In a way, this study may reconcile both authors because results obtained comparing sterilized soils to raw soils led to three conclusions when only biotic parameters were taken into account. (i) Indigenous microbiota did not exert any influence on the relationship between IP and inoculum density for GUGC where no A. euteiches could be detected under field condition-furthermore for a field which had never been sown with host plants. (ii) A rise in pea root symptoms was observed in TOPP for IP $>2$ for raw soil in comparison with sterilized soil. Organic matter levels were the highest in our soil panel leading to higher humidity that was favorable to A. euteiches a priori, as mobile zoospores need free water to infect. (iii) Microorganisms, or their products that may have been destroyed by autoclaving, showed a suppressive effect on disease expression in TOGC. Prior infection by $A$. euteiches in this parcel may have driven a shaping of the soil microbial communities governed by pea root exudates in response to this pathogen. Actually, similar results were reported by Broeckling et al. (6) for fungal community whose composition and diversity was strongly affected by root exudates from Arabidopsis thaliana or Medicago truncatula. Thus, the analysis of the diversity of soil microorganisms and potential identification of key species in the regulation of the interactions between $A$. euteiches and $P$. sativum by metagenomics may provide new directions in managing this disease.

Conclusion. The risk of root rot of pea caused by A. euteiches is a deterrent to pea cultivation, and predicting this disease constitutes a major challenge in encouraging and supporting the protein crops sector. The new prediction model presented in this study allows predicting the amount of pea root symptoms due to low A. euteiches for low inoculums, far below previous limits, by an efficient, sensitive, and accurate real time PCR method targeting ITS1 sequences from rDNA operons. First utilization of this molecular test for three field soils provided great perspective in the study of the biotic regulation of pea root rot due to $A$. euteiches and will be of particular interest in the evaluation of the effects of some compounds, microorganisms, or any disruptive process modifying soil properties, in the struggle against this oomycete.

\section{ACKNOWLEDGMENTS}

This study was supported by the AlterAgro project (call of the "Grand Réseau de Recherche VASI" funded by the "Conseil Régional de HauteNormandie" and the French "Ministère de l'Enseignement Supérieure et de la Recherche") through a Ph.D. grant to M.-A. Cannesan and financial 
support to the research developed in his thesis. This study was also funded by The European Regional Development Fund (ERDF) allocated by the European Union. We thank G. Warwick, H. Favre, and W. Edmonds for English editing; S. Taibi for her assistance in statistics; M. Maniez for her help in the determination of soil calcium content; and P.-Y. Bernard for his skills in agronomy. We would like to profusely thank anonymous reviewers for thorough comments, which helped to greatly improve this paper.

\section{LITERATURE CITED}

1. Anderson, I. C., and Cairney, J. W. G. 2004. Diversity and ecology of soil fungal communities: Increased understanding through the application of molecular techniques. Environ. Microbiol. 6:769-779.

2. Baldauf, S. L, Roger, A. J., Wenk-Siefert, I., and Doolittle, W. F. 2000. A kingdom-level phylogeny of Eukaryotes based on combined protein data. Science 290:972-977.

3. Bergès, H., Hoarau, L., Vautrin, S., Prat, E., Gautier, N., Helmstetter, N., Bellec, A., Fourment, J., Cauet, S., and Pujo, D. 2013. Aphanomyces euteiches genomic resource. French Plant Genomic Resource Center, INRA. http://cnrgv.toulouse.inra.fr/library/genomic_resource/Aeu\%20MYC

4. Bilodeau, G. J., Koike, S. T., Uribe, P., and Martin F. N. 2012. Development of an assay for rapid detection and quantification of Verticillium dahliae in soil. Phytopathology 102:331-343.

5. Bolstridge, N., Card, S., Stewart, A., and Jones, E. E. 2009. Use of rifampicin-resistant bacterial biocontrol strains for monitoring survival in soil and colonisation of pea seedling roots. N.Z. Plant Prot. 62:34-40.

6. Broeckling, C. D., Broz, A. K., Bergelson, J., Manter, D. K., and Vivanco, J. M. 2008. Root exudates regulate soil fungal community composition and diversity. Appl. Environ. Microbiol. 74:738-744.

7. Bruin, G. C. A., and Edgington, L. V. 1983. Chemical control of diseases caused by zoosporic fungi: A many sided problem. Pages 193-223 in: Zoosporic Plant Pathogens: A Modern Perspective. S. T. Buczacki, ed. Academic Press, London.

8. Byrd, R. A., Markham, J. K., and Emmerson, J. L. 1995. Developmental toxicity of dinitroaniline herbicides in rats and rabbits. I. Trifluralin. Fund. Appl. Toxicol. 26:181-190.

9. Cannesan, M.-A., Durand, C., Burel, C., Gangneux, C., Lerouge, P., Ishii, T., Laval, K., Follet-Gueye M.-L., Driouich, A., and Vicré-Gibouin, M. 2012. Effect of arabinogalactan proteins from the root caps of Pisum sativum and Brassica napus on Aphanomyces euteiches zoospore chemotaxis and germination. Plant Physiol. 159:1658-1670.

10. Cannesan, M.-A., Gangneux, C., Lanoue, A., Giron, D., Laval, K., Hawes, M., Driouich, A., and Vicré-Gibouin, M. 2011. Association between border cell responses and localized root infection by pathogenic Aphanomyces euteiches. Ann. Bot.-London 108:459-469.

11. Cannesan, M.-A., Vicré-Gibouin, M., Gangneux, C., Lerouge, P., Laval, K., and Driouich, A. 2012. Arabinogalactan proteins for use as an antiparasitic agent. International patent, EP 11305788.9.

12. Cassel, D. K., and Nielsen, D. R. 1986. Field capacity and available water capacity. In: Methods of Soil Analysis Part 2: Chemical and Microbiological Properties. 2nd ed. R. H. Miller and D. R. Keeney, eds. Agronomy Society of America, Madison, WI.

13. Davis, D. W., Shehata, M. A., and Bissonnette, H. L. 1976. Minnesota 108 pea breeding line. HortScience 11:434.

14. Diéguez-Uribeondo, J., García, M. A., Cerenius, L., Kozubíková, E., Ballesteros, I., Windels, C., Weiland, J., Kator, H., Söderhäll, K., and Martín, M. P. 2009. Phylogenetic relationships among plant and animal parasites, and saprotrophs in Aphanomyces (oomycetes). Fungal Genet. Biol. 46:365-376.

15. Engelkes, C. A., and Windels, C. E. 1994. $\beta$-Escin (saponin), oat seedlings, and oat residue in soil affects growth of Aphanomyces cochlioides hyphae, zoospores, and oogonia. Phytopathology 84:1158.

16. Forster, J. C. 1999. Soil sampling, handling, storage and analysis. Pages 49-123 in: Methods in Applied Soil Microbiology and Biochemistry. K. Alef and P. Nannipieri, eds. Academic Press, London.

17. Gaulin, E., Jacquet, C., Bottin, A., and Dumas, B. 2007. Root rot disease of legumes caused by Aphanomyces euteiches. Mol. Plant Pathol. 8:539548.

18. Grau, C. R., Muehlchen, A. M., and Tofte, J. E. 1991. Variability in virulence of Aphanomyces euteiches. Plant Dis. 75:1153-1156.

19. Grau, C. R., and Reiling, T. P. 1977. Effect of trifluralin and dinitramine on Aphanomyces root rot of pea. Phytopathology 67:273-276.

20. Hamon, C., Baranger, A., Coyne, C. J., McGee, R. J., Le Goff, I., L'anthoëne, V., Esnault, R., Rivière, J. P., Klein, A., Mangin, P., McPhee, K. E., Roux-Duparque, M., Porter, L., Miteul, H., Lesné, A., Morin, G., Onfroy, C., Moussart, A., Tivoli, B., Delourme, R., and Pilet-Nayel, M. L. 2011. New consistent QTL in pea associated with partial resistance to Aphanomyces euteiches in multiple French and American environments.
Theor. Appl. Genet. 123:261-281.

21. Heyman, F., Lindahl, B., Persson, L., Wikstrom, M., and Stenlid, J. 2007. Calcium concentrations of soil affect suppressiveness against Aphanomyces root rot of pea. Soil Biol. Biochem. 39:2222-2229.

22. Houseley, J., and Tollervey, D. 2011. Repeat expansion in the budding yeast ribosomal DNA can occur independently of the canonical homologous recombination machinery. Nucleic Acids Res. 39:87788791.

23. Huang, J., and Kang, Z. 2010. Detection of Thielaviopsis basicola in soil with real-time quantitative PCR assays. Microbiol. Res. 165:411-417.

24. Hughes, T. J., and Grau, C. R. 2007. Aphanomyces root rot or common root rot of legumes. The Plant Health Instructor. doi:10.1094/PHI-I-20070418-01

25. Ichitani, T., Kodama, T., Horimoto, K., and Ikeda, A. 1986. Aphanomyces iridis sp. nov. causing Aphanomyces basal rot of Dutch iris in Japan. Ann. Phytopathol. Soc. Jpn. 52:590-598.

26. Islam, M. T., and von Tiedemann, A. 2011. 2,4-Diacetylphloroglucinol suppresses zoosporogenesis and impairs motility of Peronosporomycete zoospores. World J. Microbiol. Biotechnol. 27:2071-2079.

27. Jacobsen, B. J., and Hopen, H. I. 1981. Influence of herbicides on Aphanomyces root rot of peas. Plant. Dis. 65:11-16.

28. King, E. B., and Parke, J. L. 1993. Biocontrol of Aphanomyces root rot and Pythium damping-off by Pseudomonas cepacia AMMD on four pea cultivars. Plant Dis. 77:1185-1188.

29. King, E. B., and Parke, J. L. 1996. Population density of the biocontrol agent Burkholderia cepacia AMMDRI on four pea cultivars. Soil Biol. Biochem. 28:307-312.

30. Kobayashi, T., Heck, D. J., Nomura, M., and Horiuchi, T. 1998. Expansion and contraction of ribosomal DNA repeats in Saccharomyces cerevisiae: Requirement of replication fork blocking (Fob1) protein and the role of RNA polymerase I. Gene. Dev. 12:3821-3830.

31. Lewis, J. A., and Papavizas, G. C. 1971. Effects of sulfur-containing volatile compounds and vapors from cabbage decomposition on Aphanomyces euteiches. Phytopathology 61:208-214.

32. Maleszka, R., and Clark-Walker, G. D. 1993. Yeasts have a four-fold variation in ribosomal DNA copy number. Yeast 9:53-58.

33. Malvick, D. K., and Percich, J. A. 1999. Identification of Pisum sativum germ plasm with resistance to root rot caused by multiple strains of Aphanomyces euteiches. Plant Dis. 83:51-54.

34. Moussart, A., Even, M. N., Lesné, A., and Tivoli, B. 2013. Successive legumes tested in a greenhouse crop rotation experiment modify the inoculum potential of soils naturally infested by Aphanomyces euteiches. Plant Pathol. 62:545-551.

35. Moussart, A., Wicker, E., Le Delliou, B., Abelard, J. M., Esnault, R., Lemarchand, E., Rouault, F., Le Guennou, F., Pilet-Nayel, M. L., Baranger, A., Rouxel, F., and Tivoli, B. 2009. Spatial distribution of Aphanomyces euteiches inoculum in a naturally infested pea field. Eur. J. Plant Pathol. 123:153-158.

36. Notredame, C., Higgins, D. G., and Heringa, J. 2000. T-Coffee: A novel method for fast and accurate multiple sequence alignment. J. Mol. Biol. 302:205-217.

37. Oyarzun, P. J., Dijst, G., Zoon, F. C., and Mass, P. W. T. 1997. Comparison of soil receptivity to Thielviopsis basicola, Aphanomyces euteiches, and Fusarium solani f. sp. pisi causing root rot in pea. Phytopathology 87:534-541.

38. Persson, L., Larsson-Wikström, M., and Gerhardson, B. 1999. Assessment of soil suppressiveness to Aphanomyces root rot of pea. Plant Dis. 83:1108-1112.

39. Persson, L., and Olsson, S. 2000. Abiotic characteristics of soils suppressive to Aphanomyces root rot. Soil Biol. Biochem. 32:1141-1150.

40. Pfender, W. F. 1984. Aphanomyces root rot. In: Compendium of Pea Diseases. D. J. Hagedorn, ed. American Phytopathological Society, St. Paul, MN.

41. Pukkila, P. J., and Skrzynia, C. 1993. Frequent changes in the number of reiterated ribosomal RNA genes throughout the life cycle of the basidiomycete Coprinus cinereus. Genetics 133:203-211.

42. Reiling, T. P., and King, T. H. 1960. Soil indexing for pea root rot and the effect of root rot on yield. Phytopathology 50:287-290.

43. Robideau, G. P., De Cock, A. W., Coffey, M. D., Voglmayr, H., Brouwer, H., Bala, K., Chitty, D. W., Desaulniers, N., Eggertson, Q. A., Gachon, C. M., Hu, C. H., Kupper, F. C., Rintoul, T. L., Sarhan, E., Verstappen, E. C., Zhang, Y., Bonants, P. J., Ristaino, J. B., and Levesque, C. A. 2011. DNA barcoding of oomycetes with cytochrome $\mathrm{c}$ oxidase subunit I and internal transcribed spacer. Mol. Ecol. Resour. 11:1002-1011.

44. Sauvage, H., Moussart, A., Bois, F., Tivoli, B., Barray, S., and Laval, K. 2007. Development of a molecular method to detect and quantify Aphanomyces euteiches in soil. FEMS Microbiol. Lett. 273:64-69.

45. Scott, D. W. 2009. Sturges' rule. WIREs Comp. Stat. 1:303-306.

46. Shimai, T., Islam, M. T., Fukushi, Y., Hashidoko, Y., Yokosawa, R., and Tahara, S. 2002. Nicotinamide and structurally related compounds show 
halting activity against zoospores of the phytopathogenic fungus Aphanomyces cochlioides. Z. Naturforsch. C. 57:323-331.

47. Shishido, M., Kubota, I., Ohashi, T., and Usami, T. 2013. Comparison of PCR assays for detection and quantification of Phomopsis sclerotioides in plant and soil. J. Gen. Plant Pathol. 79:18-27.

48. Smolinska, U., Knudsen, G. R., and Morra, M. J. 1997. Inhibition of Aphanomyces euteiches f. sp. pisi by volatiles produced by hydrolysis of Brassica napus seed meal. Plant Dis. 81:288-292.

49. Smolinska, U., Morra, M. J., Knudsen, G. R., and Brown, P. D. 1997. Toxicity of glucosinolate degradation products from Brassica napus seed meal towards Aphanomyces euteiches f. sp. pisi. Phytopathology 87:7782

50. Teasdale, J. R., Harvey, R. G., and Hagedorn, D. J. 1979. Mechanism for the suppression of pea (Pisum sativum) root rot by dinitroaniline herbicides. Weed Sci. 27:195-201.

51. Teasdale, J. R., Harvey, R. G., and Hagedorn, D. J. 1979. Factors affecting the suppression of pea (Pisum sativum) root rot (Aphanomyces euteiches) by dinitroaniline herbicides. Weed Sci. 21:467-472.

52. van den Boogert, P. H. J. F., van Gent-Pelzer, M. P. E., Bonants, P. J. M., De Boer, S. H., Wander, J. G. N., Lévesque, C. A., van Leeuwen, G. C. M., and Baayen, R. P. 2005. Development of PCR-based detection methods for the quarantine phytopathogen Synchytrium endobioticum, causal agent of potato wart disease. Eur. J. Plant Pathol. 113:47-57.

53. van der Schalie, W. H. 1983. The acute and chronic toxicity of 3,5dinitroaniline, 1,3-dinitrobenzene, and 1,3,5-trinitrobenzene to freshwater aquatic organisms. Technical Report 8305. U.S. Army Medical Bioengineering Research and Development Laboratory. Fort Detrick,
Frederick, MD.

54. Vandemark, G. J., Barker, B. M., and Gritsenko, M. A. 2002. Quantifying Aphanomyces euteiches in alfalfa with a fluorescent polymerase chain reaction assay. Phytopathology 92:265-272.

55. Vandemark, G. J., and Grünwald, N. J. 2005. Use of real-time PCR to examine the relationship between disease severity in pea and Aphanomyces euteiches DNA content in roots. Eur. J. Plant Pathol. 111:309-316.

56. Wakelin, S. A., Walter, M., Jaspers, M., and Stewart, A. 2012. Biological control of Aphanomyces euteiches root rot of pea with spore-forming bacteria. Australas. Plant Pathol. 31:401-407.

57. Wicker, E., Hullé, M., and Rouxel, F. 2001. Pathogenic characteristics of isolates of Aphanomyces euteiches recovered from pea in France. Plant Pathol. 50:433-442.

58. Wicker, E., Moussart, A., Duparque, M., and Rouxel, F. 2003. Further contributions to the development of a differential set of pea cultivars (Pisum sativum) to investigate the virulence of isolates of Aphanomyces euteiches. Eur. J. Plant Pathol. 109:47-60.

59. Woodhall, J. W., Adams, I. P., Peters, J. C., Harper, G., and Boonham, N. 2013. A new quantitative real-time PCR assay for Rhizoctonia solani AG3-PT and the detection of AGs of Rhizoctonia solani associated with potato in soil and tuber samples in Great Britain. Eur. J. Plant Pathol. $136: 273-280$.

60. Xue, A. G. 2003. Biological control of pathogens causing root rot complex in field pea using Clonostachys rosea strain ACM941. Phytopathology 93:329-335.

61. Zhang, Z., Schwartz, S., Wagner, L., and Miller, W. 2000. A greedy algorithm for aligning DNA sequences. J. Comput. Biol. 7:203-214. 